\title{
Strategi Pembelajaran Physical Distancing Guru PAUD dalam Menghadapi Pandemi Covid19
}

\author{
Sukma Nurilawati Botutihe ${ }^{\varpi_{1}}$, Mardia Bin Smith ${ }^{2}$, Irpan A. Kasan ${ }^{3}$, Rizal Hilala ${ }^{4}$ \\ Bimbingan Konseling, Universitas Negeri Gorontalo \\ DOI: $10.31004 /$ obsesi.v5i2.919
}

\begin{abstract}
Abstrak
Penelitian ini mengkaji tentang strategi yang digunakan guru PAUD dalam menerapkan proses pembelajaran. Fokus utama kajian pada bagaimana komunikasi dan kerjasama yang dibangun guru dalam menjalankan strategi pembelajaran di masa pandemi ini. Jenis penelitiannya adalah deskriptif kualitatif dengan wawancara dan observasi sebagai media pengumpulan data. Subjek penelitian yaitu 33 guru PAUD kota Gorontalo secara purposive sampling dari 9 kecamatan. Adapun hasil temuan yang diperoleh yaitu bentuk strategi pembelajaran yang dapat diterapkan adalah pembelajaran yang dilakukan secara physical distancing melalui daring dan luring. Guru memberikan informasi kegiatan belajar dan jadwal pelaksanaan daring ataupun luring melalui aplikasi Whatsapp (WA). Secara daring, WA digunakan untuk mengirimkan bentuk video tutorial kegiatan belajar dan orang tua melaporkan pelaksanaan hasil kegiatan belajar anak. Sedangkan luring, pertemuan sekali sepekan ke rumah anak. Komunikasi dan kerjasama dalam menjalankan startegi pembelajaran physical distancing memberikan dampak positif bagi anak dalam memperoleh esensi dari tujuan pembelajaran.
\end{abstract}

Kata Kunci: physical distancing; guru; strategi pembelajaran; komunikasi; kerjasama

\begin{abstract}
This study examines the strategies used by early childhood teachers in implementing the learning process. The main focus of the study is on how communication and collaboration that teachers build in carrying out learning strategies during this pandemic. This type of research is descriptive qualitative with interviews and observations as data collection media. The research subjects were 33 teachers' Preschool in Gorontalo city by purposive sampling from 9 districts. The findings obtained are that the form of learning strategies that can be applied is learning that is carried out by physical distancing through online and offline. The teacher provides information on learning activities and online or offline implementation schedules via the Whatsapp (WA) application. Online, WA is used to send video tutorials for learning activities and parents report the implementation of the results of children's learning activities. Meanwhile, offline, meeting once a week at the child's house. Communication and cooperation in carrying out learning strategies physical distancing have a positive impact on children in obtaining the essence of learning objectives.
\end{abstract}

Keywords: physical distancing; teacher; learning strategy; communication; cooperation.

Copyright (c) 2020 Sukma Nurilawati Botutihe, Mardia Bin Smith, Irpan A. Kasan, Rizal Hilala

$\triangle$ Corresponding author:

Email Address : irmabotutihe@ung.ac.id (Gorontalo, Indonesia)

Received 26 November 2020, Accepted 3 December 2020, Published 6 December 2020 


\section{PENDAHULUAN}

Pendidikan anak usia dini (PAUD) didefinisikan sebagai suatu upaya pembinaan yang ditujukan kepada anak sejak lahir sampai dengan usia enam tahun, yang dilakukan melalui pemberian rangsangan pendidikan untuk membantu pertumbuhan dan perkembangan anak agar memiliki kesiapan dalam memasuki pendidikan lebih lanjut (Standar Nasional Pendidikan Anak Usia Dini, 2014). Bredecam dan Copple Brener menjelaskan tentang hakikat anak usia dini, khususnya anak usia prasekolah (Masitoh, 2005: 1.12-1.13) yaitu: 1) anak bersifat unik, 2) anak mengekspresikan perilakunya secara spontan, 3) anak bersifat aktif dan enerjik, 4) anak bersifat egosentris, 5) anak memiliki rasa ingin tahu yang kuat dan antusias terhadap banyak hal, 6) anak bersifat eksploratif dan berjiwa petualang, 7) anak umumnya kaya dengan fantasi, 8) anak masih mudah frustrasi, 9) anak masih kurang pertimbangan dalam bertindak, 10) anak memiliki daya perhatian yang pendek, 11) masa anak merupakan masa belajar yang paling potensial, dan 12) anak semakin menunjukkan minat terhadap teman.

Kategori usia dini yaitu sejak lahir hingga usia 6 tahun yang merupakan masa pembentukan karakter dan kepribadian anak (Sujiono, 2009: 7). Usia dini merupakan masa dimana anak mengalami pertumbuhan dan perkembangan yang pesat sehingga dikenal sebagai usia emas (golden age). Anak usia dini memerlukan pelayanan pendidikan yang tepat diberikan oleh pendidik profesional. Botutihe (2020) menjelaskan bahwa pendidik yang berlatar belakang pendidikan guru PAUD merupakan para pendidik yang telah memiliki ilmu secara akademik dan praktis dalam menjalankan amanah untuk mengajar dan mendidik anak usia dini.

Pendidik memerlukan strategi pembelajaran yang tepat untuk menjalankan proses pembelajaran pada anak usia dini. Strategi pembelajaran sebagai segala usaha guru dalam menerapkan berbagai metode pembelajaran untuk mencapai tujuan yang diharapkan (Masitoh, 2005: 6.3). Ada berbagai macam strategi pembelajaran yang dapat dipilih oleh guru Taman Kanak-kanak (TK). Pemilihan strategi pembelajaran hendaknya mempertimbangkan beberapa faktor penting, yaitu: karakteristik tujuan pembelajaran, karakteristik anak dan cara belajarnya, tempat berlangsungnya kegiatan belajar, tema pembelajaran, dan pola kegiatan. Adapun tahapan strategi pembelajaran yang umum digunakan pendidik PAUD yaitu: memahami masalah, menyusun rencana, melaksanakan rencana, dan memeriksa kembali sehingga persoalan yang dihadapi dapat diatasi.

Selama masa pandemi Covid19, proses pembelajaran belum dapat berjalan secara optimal. Hal ini dikarenakan adanya pembenahan kebijakan pembelajaran yang mengarah pada sistem pembelajaran yang nyaman dan aman untuk pendidik dan peserta didik. Anak usia dini sangat rentan terhadap penyakit atau virus apapun. Karena sistem kekebalan tubuh anak dibawah usia lima tahun belum terbangun dengan sempurna (Megawati et al., 2018: 40; Yanto et al., 2017: 61). Oleh karena itu, pelaksanaan pembelajaran pada masa pandemi Covid19 perlu dilakukan pembenahan dan perbaikan sistem pembelajaran. Apabila pembelajaran tetap dilaksanakan secara tatap muka, maka akan menimbulkan permasalahan baru pada klaster guru dan anak. Dengan demikian, dibutuhkan strategi pembelajaran yang tepat dalam penanganan penyelesaian permasalahan proses pembelajaran bagi tingkat pendidikan anak usia dini (PAUD).

Pramling Samuelsson et al. (2020: 138) melalui hasil penelitiannya menyebutkan, strategi pembelajaran usia prasekolah yang digunakan selama masa pandemi Covid19 dilakukan dengan bantuan kerja sama antara guru, orangtua dan anak melalui virtual learning. Hal serupa disambut oleh Kim (2020: 145) bahwa pembelajaran online merupakan salah satu bentuk strategi pembelajaran jarak jauh yang sedang digunakan di seluruh negara akibat pandemi Covid19 dan terdapat tiga fase strategi pembelajaran online yaitu persiapan, penerapan, dan refleksi. Pendidik diberi kesempatan untuk berinteraksi dengan anak serta pendidik didorong untuk dapat menstimulasi perkembangan dan pembelajaran anak melalui komunikasi secara online. Namun Wulandari \& Purwanta (2020) mendapati dengan 
adanya pembelajaran daring sebagian besar pencapaian perkembangan anak pada beberapa aspek selama pembelajaran daring mengalami penurunan.

Pendidik PAUD dituntut dapat merancang strategi pembelajaran yang tepat untuk digunakan dalam melaksanakan pembelajaran jarak jauh untuk anak usia dini pada masa pandemi ini, salah satunya berkenaan dengan pshysical distancing. Dalam hal ini, strategi pembelajaran physical distancing berkaitan dengan pembelajaran jarak jauh yang dilakukan secara luring (luar jaringan) dan daring (dalam jaringan). Olusola-fadumiye et al. (2020: 287) menyebutkan aplikasi atau sosial media yang dapat digunakan untuk menghubungkan antara guru, orangtua dan anak dalam melakukan pembelajaran secara daring maupun luring yaitu WhatsApp dan Facebook Messanger. Rasmitadila et al. (2020: 95) juga menyebutkan berbagai media atau platform yang dapat digunakan dalam melakukan pembelajaran jarak jauh diantaranya: Google Classroom, You Tube, Whatsapp, Worksheet, Video, Google Form, dan aplikasi Ruang Guru. Berbagai media atau aplikasi tersebut dapat digunakan pendidik PAUD dan disesuaikan dengan kebutuhan pembelajaran anak usia dini.

Pada pelaksanaan pembelajaran jarak jauh saat sekarang ini, orangtua menginginkan pembelajaran yang diberikan tidak hanya dalam bentuk tugas belajar secara terus menerus. Secara umum, orangtua merasa kesulitan jika harus memahami materi dan langkah-langkah kegiatan belajar yang akan diajarkan sendiri kepada anak (Churiyah et al., 2020: 501-502). Selain itu, para orangtua juga menginginkan pembelajaran online yang lebih interaktif, pengaturan jadwal yang fleksibel dan orangtua merasa anak tidak mampu dalam menyelesaikan tugas belajar secara mandiri (Lau \& Lee, 2020).

Anggriawan (2020) melalui hasil temuannya menjelaskan, guru prasekolah menghadapi beberapa tantangan dalam menerapkan pembelajaran selama masa pandemi Covid19, diantaranya: melibatkan anak dalam proses belajar mengajar secara online, instruksi, penyusunan kurikulum, manajemen waktu, dan permasalahan teknis. Selanjutnya infrastruktur virtual untuk pembelajaran online di Indonesia telah disiapkan dengan baik namun faktor guru dan sekolah masih memerlukan esensi pembelajaran jarak jauh, selain itu orangtua juga kurang memahami sifat kegiatan belajar mengajar yang dilakukan di rumah (Churiyah et al., 2020: 491; Lapada et al., 2020).

Saat sekarang ini, dalam melakukan pembelajaran jarak jauh bagi anak usia dini diperlukan strategi pembelajaran yang tepat agar proses pembelajaran dapat berjalan dengan baik sesuai dengan kebutuhan anak. Berdasarkan pemaparan hasil kajian diatas, perlunya strategi pembelajaran yang tepat untuk dapat diterapkan bagi anak usia dini. Salah satu strategi yang dapat dilakukan adalah strategi pembelajaran physical distancing, guru melakukan pembelajaran jarak jauh melalui daring dan pertemuan kepada orangtua dan anak secara luring dengan mematuhi protap kesehatan.

Adapun aspek yang diperlukan pendidik dalam melakukan strategi pembelajaran physical distancing yaitu komunikasi dan kerja sama yang dilakukan pendidik PAUD dalam menghadapi pandemic Covid19 di kota Gorontalo. Komunikasi berkaitan dengan penyampaian informasi oleh pendidik kepada orangtua dan anak tentang kegiatan berlajar yang dilakukan, agar orangtua dan anak dapat memahami dan melakukan kegiatan belajar dengan nyaman di rumah. Selanjutnya kerja sama yang dibangun oleh pendidik dengan orangtua untuk dapat bekerjasama dalam melakukan pembelajaran physical distancing yang akan berdampak bagi perkembangan anak. Dengan demikian yang akan dikaji dalam penelitian ini yaitu bagaimana pelaksanaan strategi pembelajaran yang dilakukan guru PAUD di Kota Gorontalo dalam menghadapi pandemi Covid19?

\section{METODOLOGI}

Jenis penelitian yang dilakukan bersifat deskriptif kualitatif mengarah pada gambaran tentang objek yang diteliti. Subjek penelitian yang digunakan adalah 33 orang guru PAUD kota Gorontalo yang dipilih secara purposive sampling dari 9 kecamatan yaitu 

DOI: 10.31004/obsesi.v5i2.919

Kota Barat, Kota Selatan, Kota Utara, Kota Timur, Dungingi, Kota Tengah, Sipatama, Sumbo Raya, dan Hulontalangi. Pengumpulan data dilakukan dengan teknik observasi dan wawancara menggunakan lembar pengamatan observasi dan pedoman wawancara. Adapun tahapan pelaksanaan penelitian dijabarkan pada gambar 1 .

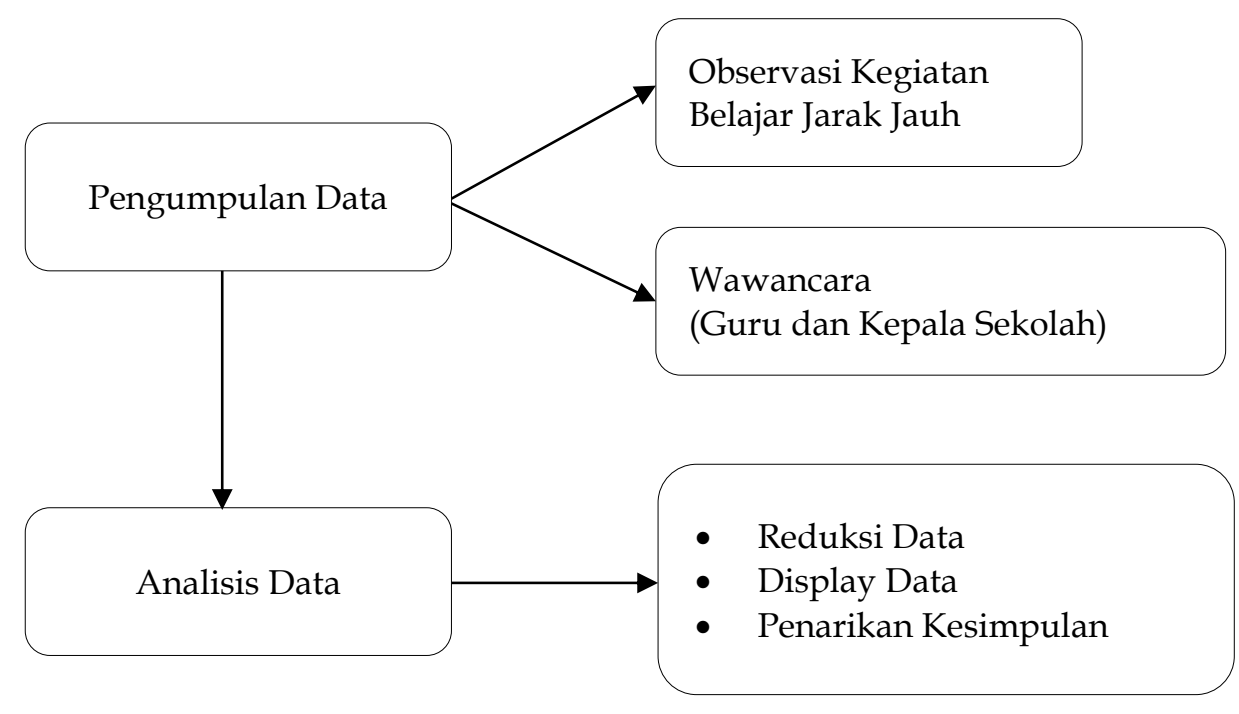

Gambar 1. Alur Pelaksanaan Penelitian

\section{HASIL DAN PEMBAHASAN}

Guru memiliki peran penting untuk membantu orangtua dalam menjalankan strategi pembelajaran physical distancing. Strategi pembelajaran ini berkaitan erat dengan pembelajaran jarak jauh. Karena dalam hal ini guru berperan dalam merancang konsep kegiatan pembelajaran, sedangkan orangtua sebagai pihak perantara menyampaikan kegiatan belajar kepada anak di rumah. Berikut hasil wawancara terkait komunikasi dan kerja sama yang dibangun pendidik dalam melakukan strategi pembelajaran physical distancing di masa pandemi Covid19 yang dijabarkan sebagai berikut:

\section{Komunikasi dalam Penyampaian Pelaksanaan Kegiatan Belajar}

Hasil penelitian menunjukkan, komunikasi yang dibangun oleh guru dalam menyampaikan kegiatan belajar kepada orang tua ditunjukkan dalam bentuk pertemuan sekali seminggu di akhir pekan (Sabtu) dan pertemuan tatap muka yang dilakukan secara luring dengan anak selama satu minggu sekali tetap dengan mematuhi protokol kesehatan. Adapun pertemuan guru kepada orangtua bertujuan untuk menyampaikan kegiatankegiatan apa saja yang akan dilakukan untuk anak selama satu pekan dan memberikan lembar portofolio kegiatan belajar anak selama satu pekan. Sedangkan pertemuan luring dilakukan untuk mengenalkan guru pada anak baik anak dalam kategori baru masuk dan anak lama, untuk memantau perkembangan anak, dan untuk membangun semangat belajar bagi anak yang akan memasuki jenjang pendidikan selanjutnya.

.... awalnya gak semua orangtua yang menyetujui rancangan kegiatan belajar yang telah kami (pihak guru dan sekolah) sepakati. Karena orangtua merasa terlalu beresiko untuk mengizinkan kami (guru kelas) untuk datang ke rumah bertemu dengan anak mereka. Setelah orangtua merasa mengeluh karena sudah disibukkan bekerja di rumah dan sesekali harus ke kantor, akhirnya orangtua setuju mengikuti program yang telah kami laksanakan untuk beberapa orangtua yang setuju..... (WGT1).

.... pertemuan dilakukan sekali seminggu. Kami (para guru kelas) sepakat memilih hari Sabtu. Karena kebanyakan orangtua murid bekerja di dinas dan hari Sabtu kan orang dinas libur. Alhamdulillah banyak orangtua yang merespon baik dengan strategi yang kami rancang ini. Walaupun hasilnya ada yang sesuai harapan atau pun yang tidak sesuai, yang penting kita coba yang terbaik untuk anak..... (WGT2). 
..... selain pertemuan dengan orangtua, kami (guru kelas) juga melakukan luring untuk anak yang mendapatkan izin orangtuanya. Luring kami rancang, karena banyak keluhan yang kami dapat dari pihak orangtua selama kegiatan belajar di rumah. Orangtua mengeluhkan kesibukan work from home (WFH) yang dilakukan orangtua dan pekerjaan rumah. Selain itu, keluhan orangtua dalam menghadapi mood anak..... (WGT3).

Pertemuan sekali seminggu antara orangtua dan guru akan berdampak pada kelancaran proses belajar anak. Selain itu, orangtua juga dapat mengetahui pencapaian perkembangan anak dengan saling bertukar informasi dengan guru mengenai kegiatan harian yang dilakukan anak selama di rumah. Hal ini sejalan dengan pendapat Irhamna (2019), informasi pengetahuan dari guru sangat bermanfaat bagi orangtua dalam menghadapi kesulitan orangtua dalam memahami perkembangan anak. Kurangnya pemahaman yang dimiliki oleh orangtua dikarenakan belum memiliki pengalaman yang cukup, belum memperoleh pelatihan yang sesuai dengan kebutuhan, dan belum pernah memperoleh pendampingan (Dong et al., 2020; Nurkolis \& Muhdi, 2020). Disamping itu Anggianita et al. (2020); Nurdin \& Anhusadar (2020) menemukan bahwa pembelajaran daring membuat tujuan pembelajaran tidak tersampaikan sepenuhnya kepada peserta didik dan masih ada guru yang kurang pemahaman dalam IPTEK apalagi guru lama, atau guru tradisional sehingga pembelajaran daring menjadi tidak menarik. Dengan demikian diperlukan strategi yang tepat untuk dapat melaksanakan pembelajaran daring agar lebih efektif dan efisien khususnya bagi anak usia dini.

Proses kegiatan belajar yang dirancang kadang kala tidak berjalan sesuai dengan harapan. Guru banyak menerima respon keluhan dari orangtua yang belum memahami bagaimana cara bermain atau bagaiman cara anak melakukan kegiatan belajar berdasarkan list dan kelengkapan bahan yang diberikan oleh guru kelas. Dalam hal ini, guru memberikan tambahan informasi untuk orangtua mengenai tahapan pelaksanaan kegiatan belajar anak melalui video pelaksanaan kegiatan bermain sesuai dengan tema dan item kegiatan yang disediakan setiap minggunya. Video tersebut dikirim guru kelas tiap minggunya kepada orangtua melalui "group WhatsApp Kelas". Dengan tujuan dapat memudahkan orangtua dalam melakukan tahapan kegiatan bermain untuk anak.

..... kami (guru kelas) banyak mendapati keluhan dari orangtua murid seperti, "gimana ini buk guru cara mainnya ke anak, saya gak ngerti". Kemudian kami para guru kelas berinisiatif membuat video kegiatan belajar anak untuk tiap minggunya kami kirim ke orangtua murid. Kegiatan belajar yang kami sediakan paling banyak 5 kegiatan dan paling sedikit 3 kegiatan..... (WGT8).

..... selain harus menyiapkan bahan kegiatan belajar untuk dibagikan ke orangtua tiap minggunya, kami (guru kelas) juga harus menyediakan tutorial kegiatan belajar. Karena banyak orangtua murid yang gak tau gimana cara melakukan kegiatan tersebut ke anak. Selain itu banyak kami dapati, kegiatan gak sepenuhnya anak yang lakukan tapi banyak campur tangan dari orangtua yang bantu anaknya dalam menyelesaikan belajar..... (WGT9).

Rata-rata media atau aplikasi yang digunakan guru dalam membagi video tutorial kegiatan belajar untuk orangtua adalah aplikasi WhatsApp. Karena aplikasi ini secara umum banyak digunakan oleh orangtua murid dalam berkomunikasi. Dengan demikian orangtua murid sudah mahir dalam menggunakan aplikasi tersebut dan guru tidak perlu mengajarkan penggunaannya. Penggunaan media bagi kelancaran pembelajaran anak di masa pandemi ini sejalan dengan hasil temuan dari Rasmitadila et al. (2020: 94-95) dan Olusola-fadumiye et al. (2020: 289-290) bahwa aplikasi atau platform yang dapat digunakan guru dalam melakukan pembelajaran online yaitu WhastApp, Facebook Messanger, You Tube, Kahoot, dan fitur aplikasi lainnya yang dapat menghubungkan antara guru dan anak dalam memberikan pengalaman pembelajaran dan berkomunikasi satu sama lain. Dengan demikian orangtua memiliki kemampuan dalam menggunakan aplikasi ini dalam proses pembelajaran daring. 


\section{Kerja Sama dalam Melaksanakan Kegiatan Belajar}

Dalam melaksanakan pembelajaran luring, guru mengajak anak untuk dapat bekerjasama dalam melaksanakan proses kegiatan belajar. Guru dituntut untuk kreatif dalam mendidik peserta didik(Ermayulis, 2020), salah satunya, mengajak anak untuk bersama-sama menjaga kebersihan, tetap menjaga jarak saat guru bertamu melakukan pembelajaran luring bersama anak di rumah. Dengan adanya konsistensi pemahaman dan penerapan guru dalam memberikan pemahaman kepada anak berupa: menjaga kontak fisik selama kegiatan belajar dan saling menyayangi walaupun tidak saling berkontak fisik, maka akan terlihat pada pemahaman anak dalam mematuhi aturan pelaksanaan pembelajaran. Anak merasa senang ketika guru bertamu ke rumah untuk melaksanakan pembelajaran luring, meskipun anak terlihat risih dalam penggunaan masker selama kegiatan belajar.

.... saya (guru kelas) melakukan luring satu minggu sekali ke rumah yang telah mendapatkan izin dari orangtuanya. Kami melakukan kegiatan belajar selama 1 jam untuk tiap-tiap anak. Karena mengingat banyak rumah yang jauh-jauh..... (WGT4).

.... saat melakukan kegiatan luring, kelihatan sekali anak senang dan menyambut saya (guru kelas) dengan senyum malu-malu mereka. Sebelumnya ada anak yang enggan memakai masker ketika luring namun ketika saya kasi pemahaman, dipertemuan selanjutnya, anak mencoba memakai masker walaupun kadang anak masih risih dan gerah ketika memakai masker di rumah..... (WGT5).

.... ketika luring berlangsung, ada beberapa anak yang merasa dekat dengan saya (guru kelas) mencoba untuk menyandar ke saya ketika belajar dan mencoba memeluk saya ketika bercanda. Kadang ada beberapa anak yang ingat aturan ada yang lupa kalau masih pandemi. Lama-kelamaan saya beri pemahaman dengan kata-kata yang sebisa mungkin anak pahami. Kemudian di hari selanjutnya anak mulai terbiasa, mencoba saling menjaga jarak, dan tetap bisa memahami arti menyayangi walaupun tidak berkontak fisik..... (WGT6).

Selain membangun kerja sama dengan anak, kerja sama dengan orangtua murid juga berperan penting bagi pelaksanaan pembelajaran di rumah tanpa guru. Dalam hal ini pelaksanaan kegiatan belajar yang biasanya dilakukan di sekolah oleh guru, namun untuk saat sekarang ini diganti oleh orangtua di rumah.

.... dalam melakukan penerapan pembelajaran seperti ini, rata-rata orangtua yang tidak bekerja di kantor memberikan respon positif terhadap program kegiatan kami ini. Orangtua merasa terbantu dengan program kegiatan belajar anak yang telah disediakan pihak sekolah. Namun, bagi orangtua yang bekerja dikantor merasa belum terbiasa dengan keadaan seperti ini. Mereka harus membagi waktu antara pekerjaan dengan program kegiatan belajar anak..... (WGT7).

.... kadang orangtua merasa sulit dalam melakukan kegiatan belajar di rumah untuk anak. Curhat orangtua umumnya kesulitan dalam menangani mood anak untuk melakukan kegiatan belajar, tidak sabar dalam menemani anak menyelesaikan kegiatan belajar secara mandiri, dan mengatur waktu antara bekerja dan waktu untuk mendampingi anak belajar.

Keadaan saat sekarang ini memerlukan kerja sama yang solid antara orangtua dan guru dalam memberikan layanan pendidikan bagi anak. Problema ini sejalan dengan hasil temuan Wardani \& Ayriza (2020: 780), kendala umum yang ditemui saat orangtua mendampingi anak dalam kegiatan belajar selama masa pandemi diantaranya orangtua kurang memahami materi kegiatan belajar yang diberikan guru, ketidak sabaran orangtua dalam mendampingi anak belajar, orangtua merasa sulit dalam menumbuhkan minat belajar anak, dan ketidak cukupan waktu yang dimiliki orangtua. Sementara itu Ayuni et al. (2021) mendapati kurangnya fasilitas yang dimiliki dan kurangnya pengetahuan orangtua sehingga menganggap pembelajaran daring sulit dilakukan. Oleh karena itu agar pembelajaran dapat berjalan lancar perlunya dukungan dari orangtua untuk dapat bekerja sama dalam memberikan layanan pendidikan yang baik untuk anak. Dengan pemberian layanan yang tepat dan optimal merupakan kunci utama dalam memperoleh kesuksesan tujuan pembelajaran untuk anak. 


\section{SIMPULAN}

Pandemi Covid19 melumpuhkan kegiatan belajar mengajar dari berbagai jenjang pendidikan termasuk pendidikan bagi anak usia dini, sehingga mengharuskan guru untuk berinovasi dalam mengembangkan strategi pembelajaran. Salah satunya dengan pembelajaran yang dilakukan secara physical distancing melalui daring dan luring. Guru memberikan informasi melalui aplikasi Whatsapp. Secara daring, guru mengirimkan video tutorial kegiatan belajar dan orang tua melaporkan pelaksanaan hasil kegiatan belajar anak. Sedangkan luring, pertemuan sekali sepekan ke rumah anak. Komunikasi dan kerjasama memberikan dampak positif bagi anak dalam memperoleh esensi dari tujuan pembelajaran, meskipun kegiatan belajar secara physical distancing.

\section{UCAPAN TERIMA KASIH}

Terimakasih kepada guru-guru PAUD di kota Gorontalo, yang telah bersedia membantu peneliti bagi kelancaran penelitian ini. Kepada semua pihak yang telah membantu, sehingga artikel ini dapat dipublikasikan.

\section{DAFTAR PUSTAKA}

Anggianita, S., Yusnira, Y., \& Rizal, M. S. (2020). Persepsi Guru terhadap Pembelajaran Daring di Sekolah Dasar Negeri 013 Kumantan. Journal of Education Research, 1(2), 177-182. https://doi.org/10.37985/joe.v1i2.18

Anggriawan, R. (2020). Preschool teachers' perspectives and challenges in online teaching and learning during COVID-19 pandemic in Indonesia. 12th Annual Conference Indonesia Focus 2020.

Ayuni, D., Marini, T., Fauziddin, M., \& Pahrul, Y. (2021). Kesiapan Guru TK Menghadapi Pembelajaran Daring Masa Pandemi Covid-19. Jurnal Obsesi : Jurnal Pendidikan Anak Usia Dini, 5(1), 414-421. https:// doi.org/10.31004/obsesi.v5i1.579

Botutihe, S. N. (2020). Pola pengelolaan pendidikan anak usia dini di Kota Gorontalo. Jurnal Obsesi: Jurnal Pendidikan Anak Usia Dini, 4(2), 883. https:// doi.org/10.31004/obsesi.v4i2.481

Churiyah, M., Sholikhan, S., Filianti, F., \& Sakdiyyah, D. A. (2020). Indonesia education readiness conducting distance learning in Covid-19 pandemic situation. International Journal of Multicultural and Multireligious Understanding, 7(6), 491. https:// doi.org/10.18415/ijmmu.v7i6.1833

Dong, C., Cao, S., \& Li, H. (2020). Young children's online learning during COVID-19 pandemic: Chinese parents' beliefs and attitudes. Children and Youth Services Review, 118(June), 105440. https:/ / doi.org/10.1016/j.childyouth.2020.105440

Ermayulis, S. (2020). Penerapan Sistem Pembelajaran Daring Dan Luring Di Tengan Pandemi Covid-19. https://www.stit-alkifayahriau.ac.id/penerapan-sistem-pembelajarandaring-dan-luring-di-tengah-pandemi-covid-19/

Irhamna. (2019). Analisis kendala yang dihadapi orang tua dalam menanamkan akhlak dan kedisiplinan belajar siswa Madrasah Darussalam Kota Bengkulu. Al-Bahtsu, 1(1), 5765. https:// doi.org/10.29300/btu.v1i1.355

Kim, J. (2020). Learning and teaching online during Covid-19: experiences of student teachers in an early childhood education practicum. International Journal of Early Childhood, 52(2), 145-158. https:// doi.org/10.1007/s13158-020-00272-6

Lapada, A. A., Miguel, F. F., Robledo, D. A. R., \& Alam, Z. F. (2020). Teachers' Covid-19 Awareness, Distance Learning Education Experiences and Perceptions towards Institutional Readiness and Challenges. International Journal of Learning, Teaching and Educational Research, 19(6), 127-144. https:/ / doi.org/10.26803/ijlter.19.6.8

Lau, E. Y. H., \& Lee, K. (2020). Parents' views on young children's distance learning and screen time during COVID-19 class suspension in Hong Kong. Early Education and 
DOI: 10.31004/obsesi.v5i2.919

Development, 00(00), 1-18. https:// doi.org/10.1080/10409289.2020.1843925

Masitoh, D. (2005). Strategi Pembelajaran TK. Pusat Penerbitan Universitas Terbuka.

Megawati, A., Hastuti, E. D., \& Sari, D. E. M. (2018). Peningkatan kualitas kesehatan anak dengan penerapan cara mencuci tangan yang benar dan pengenalan tentang obat kepada anak usia dini. Jurnal Pengabdian Kesehatan, 1(1), 39-45. https://doi.org/10.31596/jpk.v1i1.6

Nurdin, N., \& Anhusadar, L. (2020). Efektivitas Pembelajaran Online Pendidik PAUD di Tengah Pandemi Covid 19. Jurnal Obsesi : Jurnal Pendidikan Anak Usia Dini, 5(1), 686. https://doi.org/10.31004/obsesi.v5i1.699

Nurkolis, N., \& Muhdi, M. (2020). Keefektivan Kebijakan E-Learning berbasis Sosial Media pada PAUD di Masa Pandemi Covid-19. Jurnal Obsesi : Jurnal Pendidikan Anak Usia Dini, 5(1), 212. https:// doi.org/10.31004/obsesi.v5i1.535

Olusola-fadumiye, T. O., Harun, J. B., \& Ojo, J. (2020). Challenges of learning-based technology in the Covid-19 era through the use of social media implementation in the educational system. Proceedings of the 2nd Early Childhood and Primary Childhood Education (ECPE 2020), 487, 287-291.

Standar Nasional Pendidikan Anak Usia Dini, Pub. L. No. 137 Tahun 2014 (2014).

Pramling Samuelsson, I., Wagner, J. T., \& Eriksen Ødegaard, E. (2020). The coronavirus pandemic and lessons learned in Preschools in Norway, Sweden and the United States: OMEP policy forum. International Journal of Early Childhood, 52(2), 129-144. https://doi.org/10.1007/s13158-020-00267-3

Rasmitadila, Aliyyah, R. R., Rachmadtullah, R., Samsudin, A., Syaodih, E., Nurtanto, M., \& Tambunan, A. R. S. (2020). The perceptions of primary school teachers of online learning during the covid-19 pandemic period: A case study in Indonesia. Journal of Ethnic and Cultural Studies, 7(2), 90-109. https://doi.org/10.29333/ ejecs/388

Sujiono, Y. N. (2009). Konsep Dasar Pendidikan Anak Usia Dini. Indeks.

Wardani, A., \& Ayriza, Y. (2020). Analisis Kendala Orang Tua dalam Mendampingi Anak Belajar di Rumah Pada Masa Pandemi Covid-19. Jurnal Obsesi : Jurnal Pendidikan Anak Usia Dini, 5(1), 772. https://doi.org/10.31004/obsesi.v5i1.705

Wulandari, H., \& Purwanta, E. (2020). Pencapaian Perkembangan Anak Usia Dini di Taman Kanak-kanak selama Pembelajaran Daring di Masa Pandemi Covid-19. Jurnal Obsesi : Jurnal Pendidikan Anak Usia Dini, 5(1), 452. https:/ / doi.org/10.31004/obsesi.v5i1.626

Yanto, B. F., Werdiningsih, I., \& Purwanti, E. (2017). Aplikasi Sistem Pakar Diagnosa Penyakit Pada Anak Bawah Lima Tahun Menggunakan Metode Forward Chaining. Journal of Information Systems Engineering and Business Intelligence, 3(1), 61. https://doi.org/10.20473/jisebi.3.1.61-67 